\title{
Production of Hybridoma Secreting Specific Antibody against Horseradish Peroxidase Isozyme
}

\author{
Yasuji OKAI ${ }^{1}$, Yasunori YAMAGÜCHI ${ }^{2}$ and Hiroshi NAKAMÜRA ${ }^{1}$ \\ ${ }^{1}$ Department of Immunology, School of Medicine, University of Occupational \\ and Environmental Health, Japan. Kitakyushu 807, Japan \\ ${ }^{2}$ Laboratory of Embryology, Faculty of Science, Osaka City University. \\ Sumiyohi-ku, Osaka 558, Japan
}

Abstract: The specific antibody against horseradish peroxidase isozyme was prepared by a cell fussion technique between peroxidase-immunized mouse splenocyte and myeloma, P3-X63-U1 AZGR. The prepared antibody could specifically bind to Type VIII isozyme and repress its activity. In contrast, the conventional antiserum could not differentiate the specific antigen sites of isozymes.

Key words: hybridoma, specific antibody, horseradish peroxidase isozyme.

(Received 3 February 1982)

\section{Introduction}

Horseradish peroxidase has been known as a useful marker enzyme to follow the cell lineage or to detect the various antigens by the enzyme-linked antibody. The localization of this enzyme is usually detected by the bentidine-reaction or its antibody. However, it is sometimes difficult to determine the accurate position of this enzyme or corresponding antigen because of the diffuse and smear staining pattern. This may be caused by the heterogenous nature of the preparation of isozymes and antibodies.

In this paper, in order to develop a more selective and accurate method, the authors prepared successfully a specific antibody against Type VIII isozyme by hybridoma between enzyme-immunized mouse splenocyte and a myeloma cell. Then, the secreted antibodies were partially characterized.

\section{Materials and Methods}

\section{Chemicals}

Horseradish peroxidases were purchased from Sigma; crude enzyme (Type I, Lot No. 25C-9520), partially purified enzyme (Type II, Lot No. 120F-9700), acidic isozymes (Type VII, Lot No. 107C-9720, and Type VIII, Lot No. 110F-9730) and basic isozyme (Type IX, Lot No. 44C-9610). Goat anti-peroxidase serum (Miles Yeda, Lot No. 25C-9520), IgG 
Table 1. Screening for the antibody-producing hybridoma cell line by PHA test

\begin{tabular}{cccccccccccc}
\hline \multirow{2}{*}{\begin{tabular}{c} 
Dilution \\
\cline { 2 - 8 } (2 fold)
\end{tabular}} & B11 & D5 & E6 & F5 & F7 & G11 & B7 & G6 & S1 & S2 & C \\
\hline 1 & - & - & - & - & - & - & + & + & + & + & - \\
2 & - & - & - & - & - & - & + & + & + & + & - \\
3 & - & - & - & - & - & - & + & + & + & + & - \\
4 & - & - & - & - & - & - & + & + & + & + & - \\
5 & - & - & - & - & - & - & - & + & + & + & - \\
6 & - & - & - & - & - & - & - & - & - & + & - \\
7 & - & - & - & - & - & - & - & - & - & + & - \\
8 & - & - & - & - & - & - & - & - & - & + & - \\
9 & - & - & - & - & - & - & - & - & - & + & - \\
10 & - & - & - & - & - & - & - & - & - & - \\
\hline
\end{tabular}

S1 and S2 are 10 fold-diluted goat anti-peroxidase serum and prepared mouse antiperoxidase serum, which was described in materials and methods, respectively. $\mathrm{C}$ was incubated with $3 \mu \mathrm{g}$ of non-specific IgG as the control experiment.

Table 2. Effects of antibodies on the peroxidase isozymes

\begin{tabular}{cccc}
\hline \multicolumn{4}{c}{$\begin{array}{c}\text { Horseradish peroxidase activity } \\
\text { (\% of control activity*) }\end{array}$} \\
\cline { 2 - 3 } & $\begin{array}{c}\text { Isozy me type } \\
\text { VII }\end{array}$ & VII & IV \\
\hline (a) Anti-peroxidase serum & & \\
Goat & 89 & 89 & 90 \\
Mouse & 93 & 93 & 89 \\
(b) Hybridoma & supernatant & & \\
F7 & 100 & 100 & 102 \\
G6 & 101 & 82 & 100 \\
B7 & 101 & 91 & 101 \\
\hline
\end{tabular}

$2 \mu \mathrm{g}$ of goat antiserum antibody and $5 \mu \mathrm{l}$ of original mouse serum were used in each assay, respectively. Control enzyme activity at $436 \mathrm{~nm}$ was about $0.70(0.65-0.73)$ and the absorbance of substrate solution was less than 0.02 .

* Presented value was the average activity of duplicate assays.

fraction sheep anti-mouse IgG (Cappel Laboratoy, USA) and lactoperoxidase (bovine milk, Sigma) were used.

\section{Immunization and Fusions}

Six weeks-old male mouse $(\mathrm{Balb} / \mathrm{c})$ received an intraperitoneal injection of crude horseradish peroxidase (Type I, $1 \mathrm{mg}$ ) in $0.3 \mathrm{ml}$ of complete Freund adjuvant. Booster injections ( $1 \mathrm{mg}$ of the same enzyme) were given intraperitoneally at 2 and 3 weeks, respectively, after the first injection. After 1 week, the splenocyte was fused with 
mouse myeloma line (P3-X63-U1 $\left.\mathrm{AZG}^{\mathrm{R}}\right)$, which was a generous gift from Prof. T. Watanabe (Saga Medical University), according to the method (Milstein, 1981). The serum from the sacrificed mouse was used for analysis in the further experiments (Tables 1 and 2). The spleen cells $\left(2 \times 10^{7}\right)$ were fused with mouse myeloma cells $\left(2 \times 10^{6}\right)$ by incubation for $1 \mathrm{~min}$ with $1 \mathrm{ml}$ of $42.5 \%$ polyethylenegrycol 1000 and $15 \%$ of dimethylsulfoxide. Then, they were diluted stepwisely with $9 \mathrm{ml}$ of MEM medium (Flow Lab.). After centrifugation ( $800 \mathrm{rpm}$ for $10 \mathrm{~min}$ ), the cells were rediluted with $10 \mathrm{ml}$ of hypoxanthine/ aminopterin/thymidine (HAT) selection medium, and divided into 50 wells $(0.2 \mathrm{ml}$ each). After four half replacements of the selective medium were done during the next two weeks, the supernatant of each well was assayed.

\section{Ouchterlony Method}

Agar $(1.2 \%)$ in a Veronal buffer $(\mathrm{pH} 8.6)$ was coated on glass plates. 1 or $3 \mathrm{~mm}$ diameter wells were punched, and enzyme or antiserum was applied to it.

\section{Passive Hemagglutination Test}

For the antibody against horseradish peroxidase, the following test was performed. Tannic acids ( $12 \mathrm{mg} / 100 \mathrm{ml}$ saline) was incubated with sheep red blood cells (SRBC) (6\% of hematocrit value) at $37^{\circ} \mathrm{C}$ for $20 \mathrm{~min}$. After washing with saline, the SRBC was suspended to $6 \%$ of hematocrit value with $0.15 \mathrm{M}$ citrate- $\mathrm{Na}_{2} \mathrm{HPO}_{4}$ ( $\mathrm{pH} \mathrm{5.0}$ ). Then, an equal volume of peroxidase (Type I, Sigma) $(50 \mu \mathrm{g} / \mathrm{ml}$ saline) was incubated with abovementioned SRBC solution for $90 \mathrm{~min}$ at $39^{\circ} \mathrm{C}$ and stirred at room temperature overnight. After washing the enzyme-fixed SRBC with saline, the passive hemagglutination test was performed. $25 \mu 1$ of stepwisely-diluted hybridoma supernatant and the same volume of enzyme-fixed SRBC was incubated at $37^{\circ} \mathrm{C}$ in a multititer plate (Falcon) and added to the mixture with sheep IgG fraction anti-mouse IgG ( $4 \mu \mathrm{g} /$ well).

\section{Assay for Peroxidase Activity}

Peroxidase activity was assayed by a slight modification of Bergmeyer et al. (1974). $20 \mu 1$ of $30 \%$ of $\mathrm{H}_{2} \mathrm{O}_{2}$ and original guiacol (Nakarai Chemicals) was dissoved in to $50 \mathrm{ml}$ of phosphate buffer saline $(10 \mathrm{mM}, \mathrm{pH} 7.2)$, and the solution was further diluted to 10 -fold with the same PBS and $2 \mu \mathrm{g}$ of each enzyme and $1 \mathrm{ml}$ of the above-mentioned substrate solution were mixed and stood for $2 \mathrm{~min}$ at room temperature. Enzyme activity was determined from the increase of absorbance at $436 \mathrm{~nm}$. In the case for the assay of hybridoma supernatant, the sample was concentrated by salting, out with $\left(\mathrm{NH}_{4}\right)_{2} \mathrm{SO}_{4}(60 \%$ saturation, $\mathrm{pH} \mathrm{7.5).}$

\section{Results and Discussions}

Although the seven horseradish peroxidase isozymes have been already reported (Shannon 


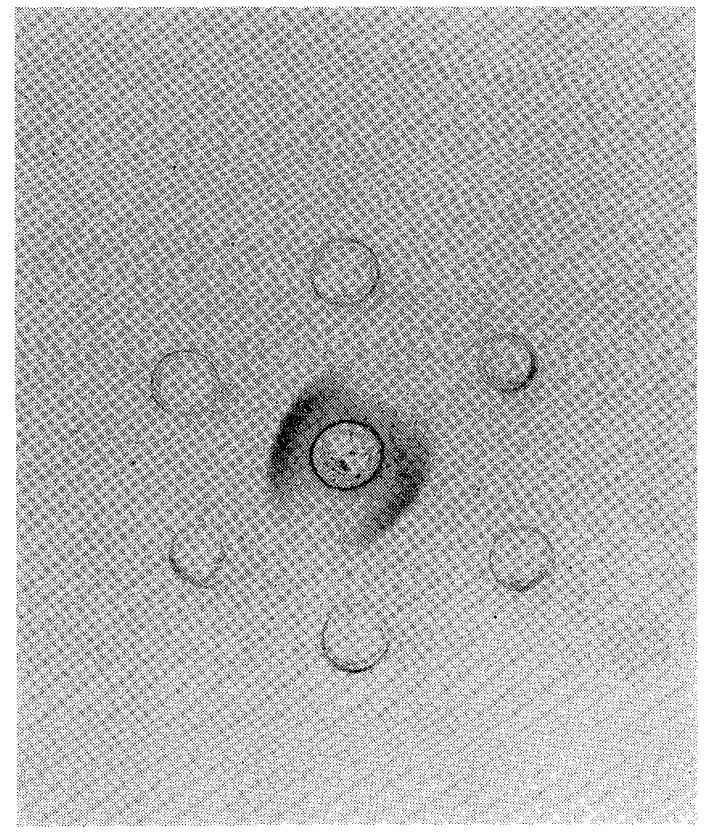

Fig. 1. Immunodiffusion analysis of various peroxidases. $2 \mu \mathrm{g}$ of each enzyme and $5 \mu \mathrm{g}$ of bovine serum albumin were applied to each well ( $1 \mathrm{~mm}$ diameter), respectively. The center well contained goat anti-peroxidase serum $(1 \mu \mathrm{g}$ of antibody).

et al., 1966), the details of their antigenicities have not been elucidated. As a preliminary experiment, the reactivity of horseradish peroxidase isozyme against the goat anti-peroxidase serum was analyzed by using the ouchterlony method. As shown in Fig. 1, Type II and IX enzymes have a common precipitation line and Type VII and VIII isozymes represent weak spur lines from the former common line. In addition, goat and mouse anti-peroxidase serums repressed all the tested isozyme reactions (Type VII, VIII and IX) to the same extent (Table 2a). These results suggest that these conventional serums could not differentiate isozyme-specific antigen sites.

Next, in order to obtain a specific antibody against peroxidase isozyme, the hybridoma cells between enzyme-immunized splenocyte and myeloma, P3-X63-U1 AZG ${ }^{\mathrm{R}}$ were prepared after the selection by the HAT (hypoxanthine, aminopterine and thymidine) medium. As a result, two clones (B7 and G6) having antibody activity against peroxidase were detected (Table 1). Furthermore, the secreted antibodies of these two clones repressed specifically Type VIII isozyme activity (Table $2 \mathrm{~b}$ ) and the dose responses for Type VIII isozyme were analyzed (Fig. 2). Also, the relationship between the inhibitory activity and the binding to enzyme was studied. After, the antibody was incubated with the enzyme, the enzyme-antibody complex was precipitated with the second antibody (rabbit anti-mouse IgG serum). Then, the free peroxidase activity in the supernatant was assayed. The result clearly demonstrated that there is a parallel relationship between the decrease of enzyme activity and the amount of added antibody (Fig. 3), which suggests that the binding of the specific antibody to Type VIII isozyme affects its activity. 


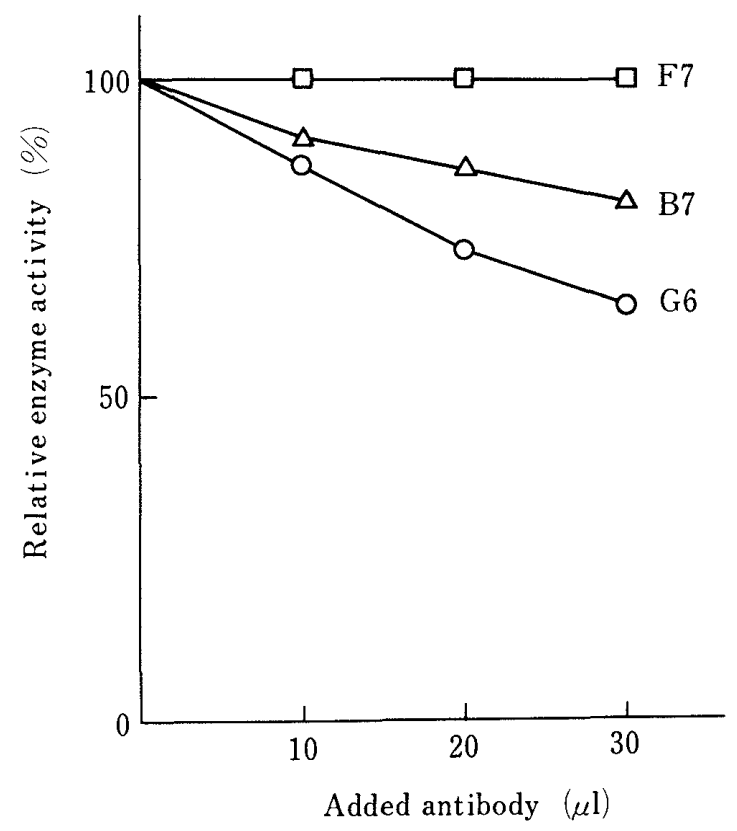

Fig. 2. Inhibitory effect by hybridoma-producing antibody for Type VIII isozyme activity. Added antibody was prepared by concentration with $50 \%\left(\mathrm{NH}_{4}\right)_{2} \mathrm{SO}_{4}$ saturation of each culture supernatant. The assay condition was the same as in Table $2 \mathrm{~b}$.

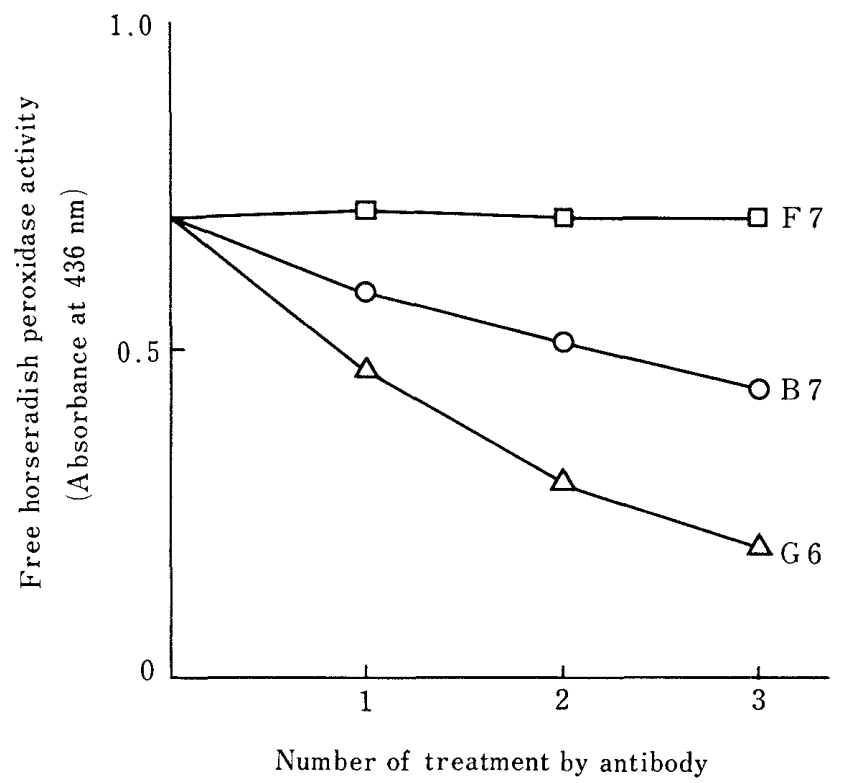

Fig. 3. Binding of hybridoma-producing antibody for Type VIII isozyme. The assay mixture contained $2 \mu \mathrm{g}$ of Type VIII enzyme, which was added to $20 \mu \mathrm{l}$ of $\mathrm{B} 7$ antibody or $30 \mu \mathrm{l}$ of $\mathrm{G} 6$ antibody. After incubation for $1 \mathrm{hr}$ at $37^{\circ} \mathrm{C}$, the antigen and antibody complex was co-precipitated with rabbit anti-mouse IgG serum (almost saturable amount) and non-specific mouse IgG $(2 \mu \mathrm{g})$. After centrifugation, the free enzyme activity in the supernatant fraction was assayed. Then, the same treatment was repeated twice more. 
Previously, Zagury et al. (1979) reported the monoclonal antibody against horseradish peroxidase by the cell fusion technique, but this antibody was not analyzed concerning specific reactivity for isozymes. The prepared antibodies as noted in this paper can differentiate isozyme-specific antigen sites, which are responsible for enzyme activity. Thus, the specific antibody produced by hybridoma may be a useful tool for the study of horeseradish peroxidases and their applications.

\title{
Acknowledgement
}

The authors would like to thank Dr. M. Furusawa (Faculty of Science, Osaka City University) for the many useful discussions.

\section{References}

Bergmeyer, H. U., Gawehn, K. \& Grassl, M. (1974): Methods of Enzymatic Analysis (Bergmeyer, H. U., ed.). Verlag Chemie Weinheim, Academic Press, New York. pp. 494-495. Milstein, C. (1981): Monoclonal antibody. Scient. Amer., 245: 56-64.

Shannon, L.H., Kay, E. \& Lew, J.H. (1966): Peroxidase isozyme from horseradish roots. J. Biol. Chem., 241: 2166-2172.

Zagury, D., Phalente, L., Bernard, J. et al. (1979): Anti-peroxidase antibody-secreting hybrid lines. Eur. J. Immunol., 9: 1-6.

\footnotetext{
ハイブリドーマによる西洋ワサビパーオキシダーゼ・アイソザイム

に対する特異抗体の産生
}

\author{
岡井 康二 ${ }^{1}$ - 山录典 ${ }^{2} \cdot$ 中村 弘 ${ }^{1}$ \\ 1産業医科大学免度学教室 2 人阪市立大学理学部発生学教室
}

要旨：西洋ワサビパーオキシダーゼは. 現在, 細胞生物辑などの分野において細胞追跡あるいは 酵素抗体法などに使われる重要なマーカーエンザイムとして知られている。しかし現在用 いられている諸方法をより選扒的かつ正確な方法とするために著者らは，本醏素のアイソ

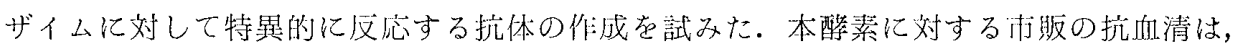

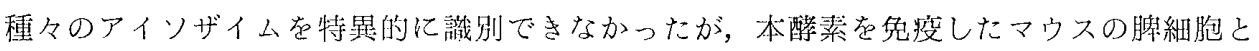
ミエローマ細胞をポリエチレングリコールにより融合させアイソザイムに特異的な抗体を 産生する細胞株の作成に成功した。作成された抗体は，アイソザイム・タイプ四にのみ選 択的に反応しその醳素活性を抑制した。

J. UOEH（産業医大誌），4 (2)：133-138 (1982) 